\title{
Apoptosis is induced in leishmanial cells by a novel protein kinase inhibitor withaferin $A$ and is facilitated by apoptotic topoisomerase I-DNA complex
}

\author{
N Sen ${ }^{1}$, B Banerjee ${ }^{1}$, BB Das ${ }^{1}$, A Ganguly ${ }^{1}$, T Sen ${ }^{2}$, S Pramanik ${ }^{3}$, S Mukhopadhyay ${ }^{3}$ and HK Majumder ${ }^{\star, 1}$
}

Protein kinase $\mathrm{C}(\mathrm{PKC})$ is an important constituent of the signaling pathways involved in apoptosis. We report here that like staurosporine, withaferin A is a potent inhibitor of PKC. In Leishmania donovani, the inhibition of PKC by withaferin A causes depolarization of $\Delta \Psi_{\mathrm{m}}$ and generates ROS inside cells. Loss of $\Delta \Psi_{\mathrm{m}}$ leads to the release of cytochrome $c$ into the cytosol and subsequently activates caspase-like proteases and oligonucleosomal DNA cleavage. Moreover, in treated cells, oxidative DNA lesions facilitate the stabilization of topoisomerase l-mediated cleavable complexes, which also contribute to DNA fragmentation. However, withaferin A and staurosporine cannot induce cleavable complex formation in vitro with recombinant topoisomerase I nor with nuclear extracts from control cells. Taken together, our results indicate that inhibition of PKC by withaferin $A$ is a central event for the induction of apoptosis and that the stabilization of topoisomerase I-DNA complex is necessary to amplify apoptotic process.

Cell Death and Differentiation (2007) 14, 358-367. doi:10.1038/sj.cdd.4402002; published online 14 July 2006

Apoptosis is thought to have evolved not only to regulate growth and development in multicellular organism, but also to guard against viral, bacterial, parasitic infection and the emergence of cancer. ${ }^{1,2}$ It is postulated that in order to promote and maintain clonality within the population, the unicellular organism developed an altruistic mechanism to control growth via apoptosis. ${ }^{3}$ The existence of apoptosis also could be useful to avoid killing by the host as suggested in the case of parasitic infection such as Leishmania donovani. ${ }^{4}$

Protein phosphorylation plays a key role in signal transduction in eucaryotic systems. Diacylglycerol activates $\mathrm{Ca}^{2+}$ and phospholipid-dependent protein kinase $C(\mathrm{PKC})$ that is associated with many cellular processes in mammalian cells including differentiation, hormone and neurotransmitter release, and gene activation. ${ }^{5,6}$ The protein kinase inhibitor staurosporine has been shown to induce programmed cell death (PCD) that involves alteration of the phosphorylation state of one or several cytosolic factors related to the signal transduction pathways. ${ }^{7}$ Other biochemical alterations related to cell cycle control and DNA replication may also contribute to the staurosporine-induced apoptosis. ${ }^{8,9}$ Staurosporine has been shown to inhibit cell cycle progression in a variety of cell lines. Staurosporine analogues $\left(\mathrm{UCN}-01^{10-13}\right.$ and CGP $41251^{14}$ ) with poor activity towards conventional PKC have been shown to interfere directly with the cell cycle machinery and to induce apoptosis. Staurosporine causes biochemical alterations in a variety of cell types irrespective of whether they expressed tumor suppressor genes p53 or Rb and leads to accumulations of CDK inhibitor $\mathrm{p}^{27 \mathrm{kip} 1}$ and not of $\mathrm{p}^{21 \mathrm{Cip} 10}$.

A steroidal lactone, Withaferin A (Figure 1), has been reported to have anti-tumor activity. ${ }^{15,16}$ Earlier studies have shown that withaferin $\mathrm{A}$ at a concentration of $3 \mu \mathrm{M}$ and above potently inhibits LPS-induced proliferation of B lymphocytes. ${ }^{17}$ At $2 \mu \mathrm{M}$ and above, withaferin A causes HUVECs (cell lines) to go into apoptosis as evidenced by the striking increase in intracellular pools of polyubiquinated proteins, which results in perturbation of many intracellular signaling pathways including activation of NF- $\kappa \beta .{ }^{18,19}$ Withaferin A can alter cytoskeletal architecture by covalently binding annexin II and stimulating its basal $\mathrm{F}$-actin crosslinking activity. ${ }^{20}$

Leishmania, a unicellular kinetoplastid protozoan parasite, is the causative agent of leishmaniasis. With the spread of human immunodeficiency virus (HIV), the parasites pose a much greater threat than before. To make the situation even worse, some parasite strains have developed resistance against the classical antimonial drugs, like sodium stibogluconate. The second line of drugs, amphotericin B and pentamidines although used clinically, are very toxic. ${ }^{21}$ Therefore, improved drug therapy is still desirable and the need for newer intervention strategies is clear and justified. In search for such strategies, protein kinases of Leishmania offer the most attractive targets.

${ }^{1}$ Division of Infectious Diseases, Indian Institute of Chemical Biology, 4, Raja SC Mullick Road, Kolkata 700 032, India; ${ }^{2}$ Department of Biochemistry, Dr BC Roy Postgraduate Institute of Basic Medical Sciences, Calcutta University, 244, B, AJC Bose Road, Kolkata 700 020, India and ${ }^{3}$ Department of Chemistry, Indian Institute of Chemical Biology, 4, Raja SC Mullick Road, Kolkata 700 032, India

${ }^{*}$ Corresponding author: HK Majumder, Division of Infectious Diseases, Molecular Parasitology Laboratory, Indian Institute of Chemical Biology. 4, Raja SC Mullick Road, Kolkata 700 032, India. Tel: + 91332412 3207; Fax: + 91332473 5197; E-mail: hkmajumder@iicb.res.in

Keywords: protein kinase; Withaferin A; staurosporine; DNA topoisomerase I; apoptosis; Leishmania donovani

Abbreviations: ROS, reactive oxygen species ; PI, propidium iodide; $\Delta \Psi \mathrm{m}$, mitochondrial transmembrane potential; NAC, $N$-acetyl-cysteine; DMSO, dimethyl sulfoxide; CPT, camptothecin; DEVD-AFC, Asp-Glu-Val-Asp-7-amino-4-trifluoromethyl coumarin; TUNEL, terminal deoxynucleotidyltransferase enzyme-mediated dUTP end labeling; VAD-fmk, Val-Ala-Asp-fluoromethyl ketone; FITC, fluorescein isothiocyanate; DTT, dithiothreitol; $\mathrm{H}_{2} \mathrm{DCFDA}, 5$-(and -6)-chloromethyl-2',7'dichlorodihydro-fluorescein diacetate acetyl ester

Received 16.1.06; revised 15.5.06; accepted 25.5.06; Edited by M Piacentini; published online 14.7.06 
In the present study, we have shown for the first time that an anti-tumor agent withaferin $A$ is a potent inhibitor of PKC like staurosporine. Unlike higher eucaryotes, inhibition of PKC inside leishmanial cells is sufficient to induce apoptosis like death in a previously unknown manner. We have analyzed nuclear, mitochondrial and cytosolic changes

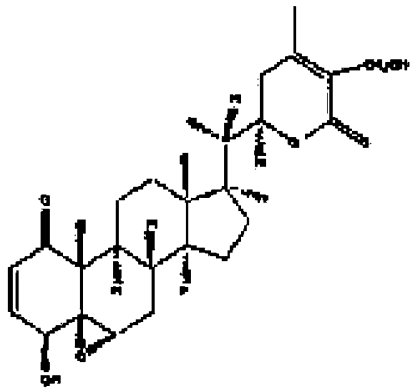

WITHAFERIN A<smiles>CN[C@H]1C[C@@H]2O[C@](C)([C@@H]1OC)n1c3ccccc3c3c4c(c5c6ccccc6n2c5c31)C(=O)NC4</smiles>

STAUROSPORINE

Figure 1 Structure of withaferin A and staurosporine

a

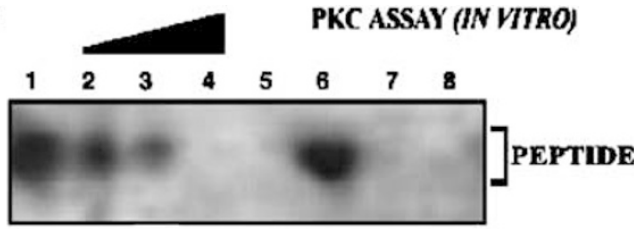

b
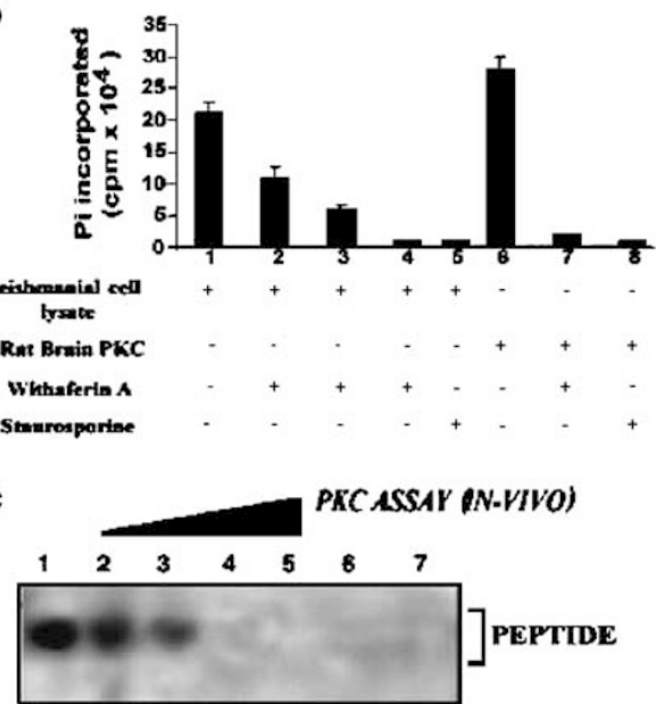

associated with apoptosis after inhibition of PKC. Finally, we provide evidences for the functional role of topoisomerase I-DNA complexes in chromatin fragmentation during withaferin A- and staurosporine-mediated apoptosis.

\section{Results}

Withaferin A inhibits PKC both in vitro and in vivo. Leishmanial cell extract prepared as described in Materials and Methods was tested for its activity to phosphorylate the peptide HCV (1487-1500). ${ }^{22}$ It was observed that the phosphorylation of the peptide by leishmanial cell is decreased in a dose-dependent manner in the presence of withaferin $A$ (Figure 2a). The extent of phosphorylation of the peptide by incorporation of ${ }^{32} \mathrm{P}$-labeled $\mathrm{Pi}$ was monitored by scintillation counting and is shown in Figure $2 \mathrm{~b}$. At $5 \mu \mathrm{M}$ concentration of withaferin $A$, the phosphorylation of the peptide was decreased to $50 \%$ (Figure $2 a$ and b, lane 2) compared to untreated cell lysates (Figure $2 a$ and b, lane 1), and at $10 \mu \mathrm{M}$, it was decreased to $74 \%$ (Figure $2 \mathrm{a}$ and $\mathrm{b}$,

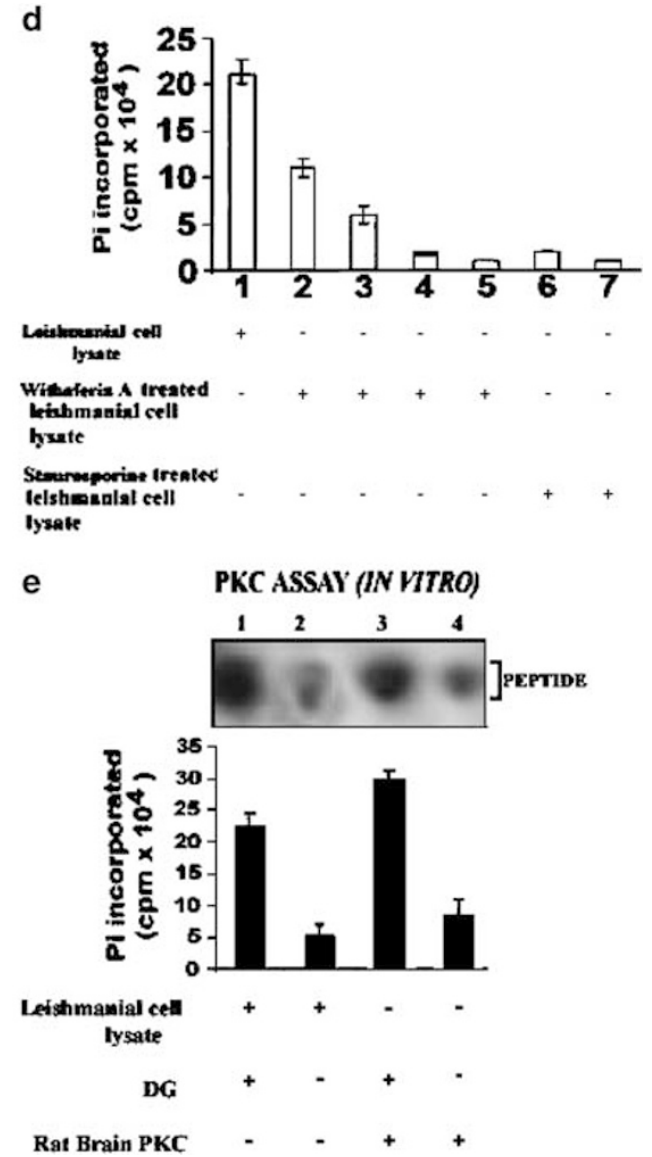

Figure 2 Inhibition of phosphorylation of the peptide (HCV (1487-1500)) by withaferin A and staurosporine. (a) Leishmanial cell lysate was analyzed for PKC activity in the absence of withaferin A (lane 1) and in the presence of $5 \mu \mathrm{M}$ (lane 2), $10 \mu \mathrm{M}$ (lane 3) and $15 \mu \mathrm{M}$ (lane 4) of withaferin $\mathrm{A}$ and with $15 \mu \mathrm{M}$ of staurosporine (lane 5). Kinase activity of rat brain PKC was assayed in the absence (lane 6) and in the presence of $15 \mu \mathrm{M}$ withaferin $\mathrm{A}$ (lane 7) and $15 \mu \mathrm{M}$ of staurosporine (lane 8) separately as described in Materials and Methods. (b) Incorporation of ${ }^{32} \mathrm{P}$ into the peptide was measured in differently treated cell lysates as mentioned in (a). (c) Leishmanial cells were treated with $0.2 \%$ DMSO for $14 \mathrm{~h}$ (lane 1), with $15 \mu \mathrm{M}$ of withaferin A for $1 \mathrm{~h}$ (lane 2), $1.5 \mathrm{~h}$ (lane 3 ), $2 \mathrm{~h}$ (lane 4 ) and $3 \mathrm{~h}$ (lane 5 ) and with $15 \mu \mathrm{M}$ of staurosporine for $1.5 \mathrm{~h}$ (lane 6 ) and $3 \mathrm{~h}$ (lane 7), and their cell lysates were used to measure kinase activities using the peptide substrate as described in Materials and Methods. (d) Incorporation of ${ }^{32} \mathrm{P}$ into the peptide was measured in differently treated cell lysates as mentioned in (c). (e) Incorporation of ${ }^{32} \mathrm{P}$ into the peptide by leishmanial cell lysates (lanes 1 and 2 ) and by rat brain PKC (lanes 3 and 4) in the presence (lanes 1 and 3 ) and in the absence (lanes 2 and 4) of DG 
lane 3). At $15 \mu \mathrm{M}$ concentration, no labeled peptide band was detected (Figure 2a and b, lane 4). As a positive control, we added staurosporine in leishmanial cell extracts and found that phosphorylation of the peptide is reduced to the extent of 92\% (Figure $2 a$ and $b$, lane 5). To prove whether withaferin A or staurosporine has direct inhibitory effects on rat brain PKC, we added withaferin A and staurosporine separately to the enzyme in the presence of this peptide substrate. It was observed that phosphorylation of the peptide is reduced by both withaferin A and staurosporine to the extent of $95 \%$ (Figure $2 \mathrm{a}$ and $\mathrm{b}$, lane 7 ) and $98 \%$ (Figure $2 \mathrm{a}$ and $\mathrm{b}$, lane 8 ), respectively, at $15 \mu \mathrm{M}$ concentration compared to untreated cells (Figure $2 a$ and $b$, lane 6 ).

To see whether withaferin A has the ability to inhibit PKC activity inside leishmanial cells, we treated exponentially growing leishmanial cells with withaferin $\mathrm{A}(15 \mu \mathrm{M})$ or staurosporine $(15 \mu \mathrm{M})$ separately up to $8 \mathrm{~h}$. At different time periods, cells were pelleted down and solubilized as described in Materials and Methods. The solubilized materials were tested for their activities to phosphorylate the peptide HCV (1487-1500) (Figure 2c and d). The phosphorylating ability of withaferin A-treated cell lysates was reduced to the extent of $50,76,84$ and $92 \%$, respectively, after $1 \mathrm{~h}$ (Figure $2 \mathrm{c}$ and d, lane 2), $1.5 \mathrm{~h}$ (Figure $2 \mathrm{c}$ and d, lane 3 ), $2 \mathrm{~h}$ (Figure $2 \mathrm{c}$ and $\mathrm{d}$, lane 4) and $3 \mathrm{~h}$ (Figure $2 \mathrm{c}$ and $\mathrm{d}$, lane 5) of treatment compared to healthy growing leishmanial cell extracts (Figure 2c and d, lane 1). Treatment with staurosporine reduced the phosphorylation of the peptide to the extent of $89 \%$ (Figure 2c and d, lane 6) and 95\% (Figure 2c and d, lane 7 ) after 2 and $3 \mathrm{~h}$, respectively. We found that the activity was reduced to the extent of $76 \%$ by leishmanial cell lysates and to the extent of $67 \%$ by rat brain PKC in the absence of DG in the reaction mixture (Figure $2 \mathrm{e}$ ).

Withaferin A inhibits growth of $L$. donovani promastigotes, induces depolarization of mitochondrial membrane potential and releases cytochrome $c$ into the cytosol. L. donovani AG83 promastigotes $\left(2.5 \times 10^{6}\right.$ cells/ $\mathrm{ml}$ ) were incubated with $15 \mu \mathrm{M}$ of withaferin $\mathrm{A}$ for $7 \mathrm{~h}$, following which the numbers of live promastigotes were counted by Trypan blue exclusion method. After $5 \mathrm{~h}, 70 \%$ growth was inhibited and this continued to the extent of $85 \%$ after $6 \mathrm{~h}$ of incubation and after $7 \mathrm{~h}$ only $2 \%$ live promastigotes were present (Figure $3 \mathrm{a}$ ). To investigate the mode of cell death, we stained both treated and untreated cells with annexin $\mathrm{V}$ and $\mathrm{PI}$. Apoptotic cells have condensed nuclei that are negative for $\mathrm{PI}$ and have integrated plasma membrane but PS translocates on the outer membrane, which can be detected by staining with annexin V. After $4 \mathrm{~h}$ of treatment with withaferin A, more than $25 \%$ cells undergo apoptosis and this was increased to the extent of $67 \%$ after $6 \mathrm{~h}$. We also detected an increase in the number of annexin V- and PI-positive cells representing necrotic cells,
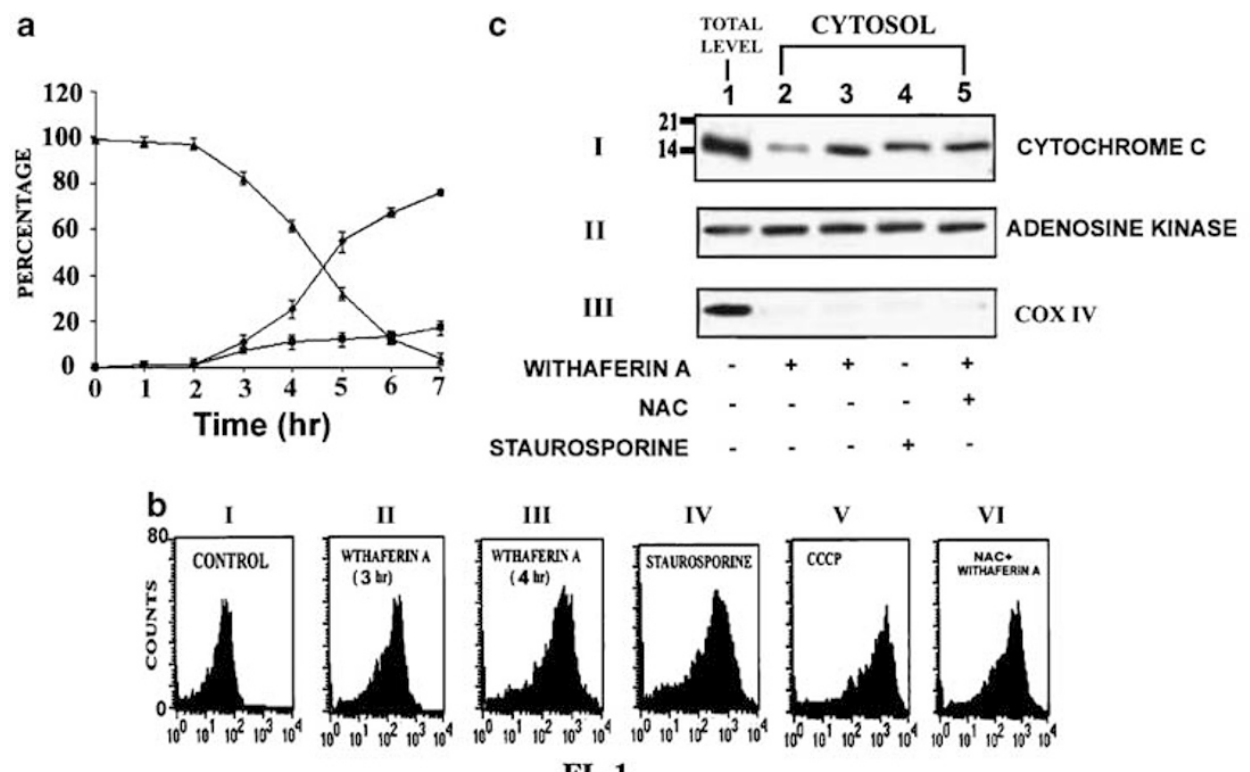

FL-1

GREEN FLUORESCENCE INTENSITY

Figure 3 Treatment with withaferin A increases the number of apoptotic cells, and induces loss of mitochondrial membrane potential and release of cytochrome $c$ into the cytosol. (a) L. donovani promastigotes were cultured in the presence of $15 \mu \mathrm{M}$ withaferin A for $7 \mathrm{~h}$. Percentage of viable promastigotes $(\mathbf{\Delta})$ was measured by Trypan blue exclusion method. Percentage of apoptotic cells $(\bullet)$ and necrotic cells $(\boldsymbol{\square})$ was measured during treatment with $15 \mu \mathrm{M}$ of withaferin A for different time periods by double staining with annexin $\mathrm{V}$ and $\mathrm{PI}$ as described in Materials and Methods. Data are expressed as mean \pm S.D. of three independent experiments. (b) Flow cytometry analysis of mitochondrial membrane potential after treatment with $0.2 \%$ DMSO alone (I), $15 \mu \mathrm{M}$ withaferin A for $3 \mathrm{~h}$ (II) and $4 \mathrm{~h}$ (III). This was also determined after treatment with staurosporine (IV) and CCCP (V) alone and with antioxidant like NAC, before treatment with withaferin A (VI). FL1 channel indicates mean green fluorescence intensity of JC1. (c) Western blot analysis of the release of cytochrome $c$ into the cytosol of differently treated cells. As loading controls, cytosolic fractions from differently treated cells were analyzed for the presence of adenosine kinase (II) and COX IV (III) by Western blotting. Lane 1: total level of cytochrome $c$ (I), adenosine kinase (II) and COX IV (III) in untreated leishmanial cells; lanes 2 and 3 : cells treated with withaferin A for 2 and $3 \mathrm{~h}$, respectively; lane 4: cells treated with staurosporine for $2 \mathrm{~h}$; lane 5 : cells treated with NAC before treatment with withaferin A. Position of molecular weight markers $\left(\times 10^{-3}\right)$ is shown in the left of top panel 
concomitant with a decrease in the number of live (annexin $\mathrm{V}$ - and PI-negative) cells. The number of necrotic cells remained more or less $10 \%$ throughout the experiment (Figure 3a).

To investigate whether $\Delta \Psi_{\mathrm{m}}$ is lost in withaferin A-treated cells during apoptosis, a time-course study of $\Delta \Psi_{\mathrm{m}}$ was performed with withaferin $\mathrm{A}$ or staurosporine. $\Delta \Psi_{\mathrm{m}}$ was measured with the mitochondrial membrane potential sensitive dye JC1, which undergoes a transition from molecular aggregation to molecular monomer formation that can be detected by a shift in fluorescence from red to green during depolarization of mitochondrial membrane potential. ${ }^{23}$ As shown in Figure 3b, on exposure of leishmanial cells to $15 \mu \mathrm{M}$ withaferin A for $3 \mathrm{~h}$ (II) and $4 \mathrm{~h}$ (III) and to $15 \mu \mathrm{M}$ staurosporine for $3 \mathrm{~h}$ (IV), the uptake of this dye by the mitochondria decreased compared to control cells (I) and this was measured by an increase in green fluorescence intensity in the cytosol. When cells were treated with antioxidants like NAC, before the treatment with withaferin $A$, depolarization of $\Delta \Psi_{\mathrm{m}}$ is not prevented $(\mathrm{VI})$. This was evidenced by the fact that there is no shift in total cell population to the right side of FL-1 channel (Figure $3 b$ ). Our results suggest that ROS are not responsible for the loss of $\Delta \Psi_{\mathrm{m}}$.

Cytochrome $c$ is a component of the mitochondrial electron transport chain and is present in the inter-membrane space. Disruption of the outer mitochondrial membrane by apoptotic stimuli results in the release of cytochrome $c$ into the cytoplasm where it initiates activation of caspases like proteases leading to apoptosis. ${ }^{23}$ We have shown by Western blotting that withaferin $A$ or staurosporine treatment causes cytochrome $c$ accumulation in the cytoplasm (Figure 3c, lanes 2-4). In addition, treatment with antioxidants like NAC before the treatment with withaferin A cannot prevent the release of cytochrome $c$ into the cytosol (lane 5). As controls we have checked the presence of adenosine kinase (a constitutive cytosolic protein) and the absence of COX IV (a mitochondrial protein) in the cytosol of $L$. donovani promastigotes treated with or without withaferin $A$ and staurosporine.

Loss of mitochondrial membrane potential induces formation of ROS inside cells, which causes a decrease in cellular GSH level and induces oxidative DNA lesions. When $L$. donovani promastigotes were treated with withaferin A, ROS are generated inside cells, which can be measured fluorimetrically by conversion of $\mathrm{H}_{2}$ DCFDA to highly fluoroscent 2,7-dichlorofluorescein. The level of ROS in withaferin A-treated cells remains four-fold higher compared to the level of ROS in control cells throughout the experiment (Figure 4a). When cells were treated with NAC before the treatment with withaferin $A$, the level of ROS generation was reduced to the extent of $60 \%$ compared to that in DMSO-treated control cells.

GSH is an important molecule for protecting kinetoplastids from ROS or toxic compounds and may induce a loss of $\Delta \psi_{\mathrm{m}}$. As shown in Figure $4 \mathrm{~b}$, withaferin A causes $30 \%$ decrease in GSH level after $2 \mathrm{~h}$ and the effect was more pronounced after $4 \mathrm{~h}$ of treatment with withaferin $\mathrm{A}$. When cells were preincubated with NAC, before treatment with withaferin $A$ the decrease in GSH level was protected significantly. Time kinetics analysis reveals that loss of $\Delta \Psi_{\mathrm{m}}$ leads to generation of ROS inside cells.

Generation of ROS inside cells causes oxidative DNA lesions such as formation of oxidized bases, abasic sites and strand breaks. ${ }^{24,25}$ Here, we investigated the generation of such lesions by withaferin A. Leishmanial cells were permeabilized and exposed to formamidopyridine DNA glycosylase (Fpg), an enzyme that converts oxidized purines (e.g. 8oxoguanosine) into DNA single-strand breaks. By using the alkaline comet assay, we observed that Fpg-induced singlestrand breaks in withaferin A-treated cells were increased compared to control cells treated with Fpg. These results suggest that treatment with withaferin $A$ in leishmanial cells causes oxidative DNA damage. Treatment with NAC before treatment with withaferin $A$ decreased the amount of singlestrand breaks induced by withaferin A (Figure 4c).

Withaferin A- or staurosporine-induced oxidative DNA lesions cause topoisomerase I-DNA complex formation inside cells, but they do not inhibit the catalytic activity of topoisomerase I nor do they form the cleavage complexes in vitro. In order to find out whether withaferin $A$ and staurosporine can stabilize covalent complexes of topoisomerase I and DNA in intact cells, we carried out immunoband depletion experiments with $L$. donovani promastigotes. Nuclear fraction was prepared from untreated as well as from drug-treated promastigotes and subjected to SDS-PAGE. If topoisomerase I can form a covalent complex with genomic DNA inside cells, then the complex cannot enter the gel. On the other hand, if topoisomerase I does not form a complex with DNA and remains free, it will enter the gel. The presence of topoisomerase I was detected by immunoblotting as described in Materials and Methods. The immunoband depletion data are summarized in Figure 5a. It was observed that the immunoband of topoisomerase I gradually disappeared when withaferin A was applied to the medium at $20 \mu \mathrm{M}$ concentration for 3,4 and $5 \mathrm{~h}$ (lanes 2-4). The extent of topoisomerase I immunoband depletion was similar to that obtained by $20 \mu \mathrm{M}$ of staurosporine (lane 5) and $50 \mu \mathrm{M}$ of CPT for $3 \mathrm{~h}$ (lane 6). Thus, we can surmise that withaferin $A$ induces cleavable complex stabilization inside $L$. donovani promastigote cells. Treatment with NAC before treatment with withaferin $A$ causes reappearance of immunoband of LdTOPIS, as cleavable complex formation is prevented (lane 7). The result suggests that oxidative stress is responsible for the stabilization of topoisomerase I-DNA complex inside cells. It should be mentioned here that topoisomerase I of Leishmania is a heterodimer and the catalytic site (SKXXY) is present in the small subunit, which is involved in the formation of topoisomerase I-DNA covalent complex. So we have used the antibody raised against the small subunit of topoisomerase I to study immunoband depletion assay.

To know whether withaferin A or staurosporine has the ability to interact directly with topoisomerase I in vitro, we carried out DNA relaxation assay (Figure $5 b) .{ }^{26}$ When added together with DNA and enzyme, withaferin A could not inhibit the relaxation of supercoiled DNA at concentrations ranging from 20 to $80 \mu \mathrm{M}$ (lanes 3-6). Lane 2 shows the relaxation of supercoiled pHOT1 DNA (lane 1 ) by $2 \mathrm{U}$ of topoisomerase I. 

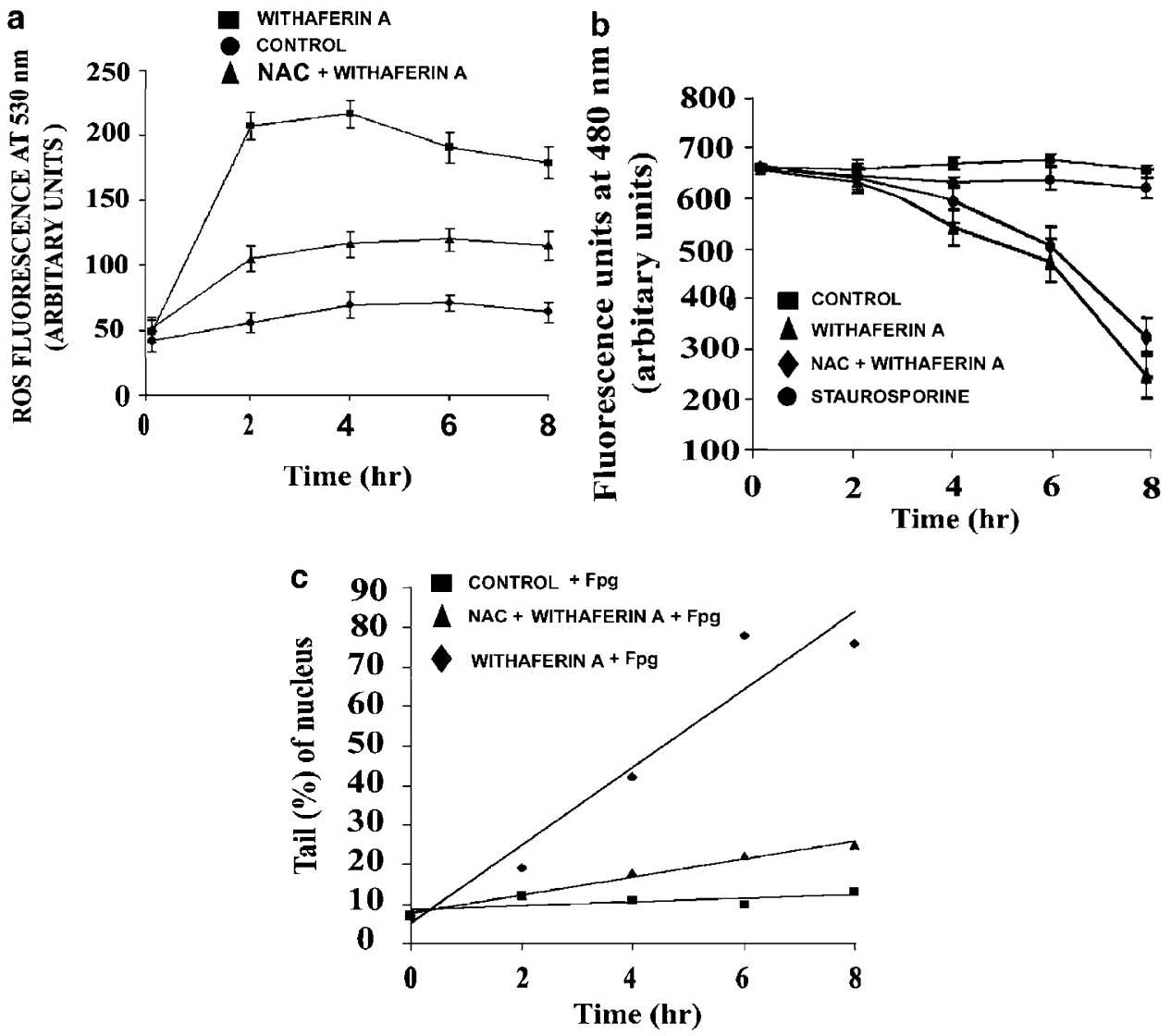

Figure 4 Withaferin A induces oxidative stress, causes decrease in GSH level and leads to subsequent DNA lesions. (a) Generation of ROS was measured using fluoroscent dye $\mathrm{H}_{2}$ DCFDA after treatment with $0.2 \%$ DMSO alone $(\boldsymbol{O}), 15 \mu \mathrm{M}$ withaferin $\mathrm{A}(\boldsymbol{\square})$ and with NAC before treatment with withaferin $\mathrm{A}(\boldsymbol{\Delta})$. Data are expressed as mean \pm S.D. of three independent experiments. (b) The intracellular GSH level was measured after treatment with $0.2 \%$ DMSO alone $(\boldsymbol{\square}), 15 \mu \mathrm{M}$ withaferin $\mathrm{A}(\mathbf{\Lambda})$ and $15 \mu \mathrm{M}$ staurosporine $(\bullet)$ separately and with NAC $(\bullet)$ before treatment with withaferin A. (c) Leishmanial cells were treated with $0.2 \%$ DMSO $(\boldsymbol{\square}), 15 \mu \mathrm{M}$ of withaferin A for different time periods $(\bullet)$ and with NAC before treatment with $15 \mu \mathrm{M}$ of withaferin $\mathrm{A}(\mathbf{\Delta})$ and exposed to Fpg for $30 \mathrm{~min}$. DNA single-strand breaks were analyzed by determining tail percentage using comet assay

Lanes 7 and 8 show that staurosporine also has no inhibitory effect on the activity of topoisomerase I. As a positive control, when CPT was added together with enzyme and DNA, the activity of topoisomerase I was inhibited almost to the extent of $80 \%$ (lane 9). CPT also has the ability to inhibit the relaxation of supercoiled DNA even in the presence of withaferin $A$ (lane 10). This result suggests that withaferin A and staurosporine do not inhibit topoisomerase I in vitro.

To know whether withaferin $A$ or staurosporine can stabilize covalent DNA-topoisomerase I complex in vitro, we performed cleavage assay as described in Materials and Methods. We found that withaferin A was unable to convert closed circular DNA (form I) to nicked circular DNA (form II) at concentrations ranging from 20 to $80 \mu \mathrm{M}$ (Figure $5 \mathrm{c}$, lanes 3-6). At $60 \mu \mathrm{M}$ (lane 7) and $80 \mu \mathrm{M}$ (lane 8) concentrations of staurosporine, form I DNA was not converted to form II DNA. Camptothecin, the well-studied topoisomerase I inhibitor, has been shown to stabilize the 'cleavable complex'. ${ }^{27}$ At $50 \mu \mathrm{M}$ concentration of CPT, closed circular DNA (form I) was converted to nicked circular DNA (form II) in the presence of $40 \mathrm{U}$ of topoisomerase I (lane 9). CPT can also induce cleavable complex formation even in the presence of withaferin A (lane 10). Lane 2 shows the formation of nicked product when the covalent complex was trapped with SDS and proteinase $\mathrm{K}$. This result shows that withaferin $\mathrm{A}$ or staurosporine cannot stabilize the 'cleavable complex' in vitro.

To understand whether withaferin A or staurosporine has any direct effect on LdTOPILS in vivo, we have isolated nuclear extracts from control cells as well as from withaferin $A$ $(15 \mu \mathrm{M})$ - or staurosporine $(15 \mu \mathrm{M})$-treated cells and relaxation assays were carried out with pHOT1 DNA (Figure $5 \mathrm{~d}$ ). It was found that each extract can relax the supercoiled DNA (lanes 2 and 3) and the enzyme activities are inhibited in the presence of CPT (lanes 4 and 5). However, CPT-treated nuclear extract was unable to relax supercoiled pHOT1 DNA (lane 6). The results suggest that withaferin $A$ and staurosporine have no direct effect on topoisomerase I.

Both activation of caspase-like proteases and topoisomerase I-DNA complexes attribute to DNA fragmentation during apoptosis. The release of cytochrome $c$ causes activation of caspases like proteases inside cells, as demonstrated by the ability of withaferin A-treated cell lysates to cleave DEVD-AFC (a fluoregenic peptide substrate) significantly, compared to untreated cell lysates (Figure 6a). Treatment with VAD-fmk (a caspase inhibitor) 
before treatment with withaferin A inhibits DNA fragmentation to the extent of $47 \%$, which further supports the involvement of caspase-like proteases in DNA fragmentation. From time kinetic analysis, we have found that the formation of the topoisomerase I-DNA complexes induced by withaferin A was coincident with the activation of caspase-like proteases inside cells. Furthermore, withaferin A-treated leishmanial cells exhibited an increase in the percentage of DNA fragmentation at the time when topoisomerase I-DNA complexes were detected. Treatment with NAC before treatment with withaferin $A$ prevents stabilization of topoisomerase I-DNA complex (Figure 5a) and also decreases DNA fragmentation to the extent of $43 \%$ (Figure 6b). These results suggest that oxidative stress-

a

IMMLNOBAND DEPLETION

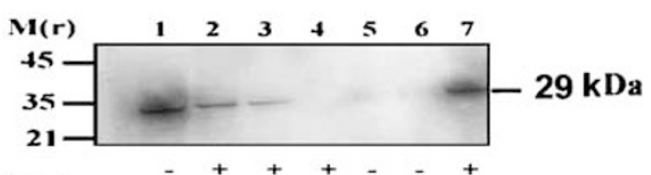

WTTHAFERIN A

STALROSPORINE

NAC:

$-\quad-\quad+-\frac{-}{-}$

CPT

b

RELAXATION ASSAY

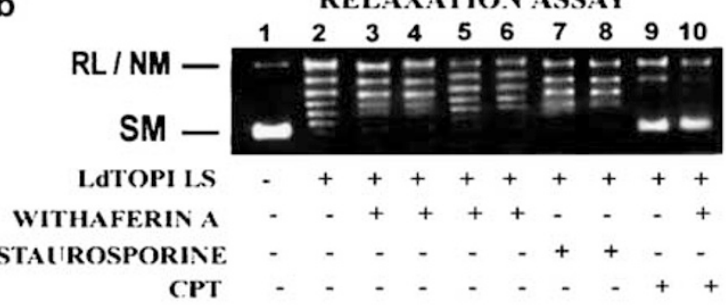

C

CLEAVACIE ASSAY

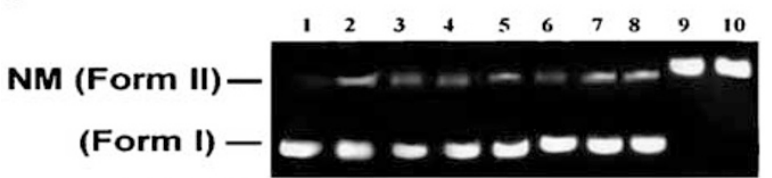

LdTOPILS - +++++++++

WITHAFERIN A - - + + + + - - +

STAUROSPORINE - - - - - - + + - -

CPT - - - - $--_{-}-++$

d

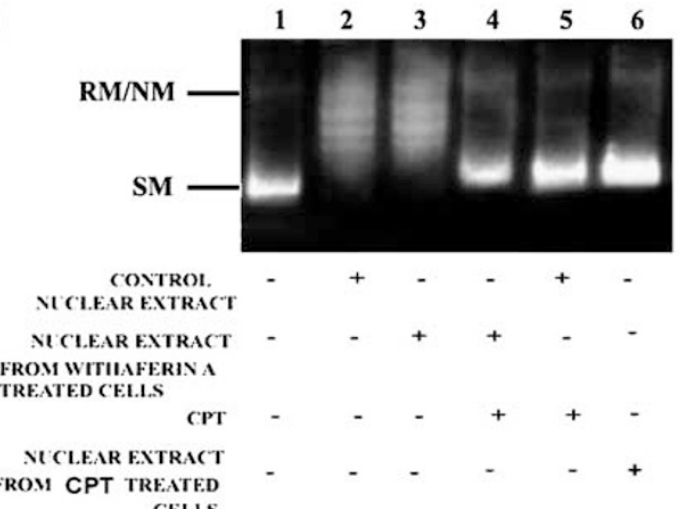

CEIIS induced topoisomerase I-DNA complex is also involved in DNA fragmentation along with caspase-like proteases.

To further establish the involvement of topoisomerase I in apoptosis, we treated topoisomerase I-deficient yeast cells (CY154) as well as wild-type cells (CY184) with withaferin A, staurosporine and CPT separately. CPT is a specific inhibitor of topoisomerase I; so in the absence of topoisomerase I in CY154 yeast cells, the sensitivity of this drug is reduced in these cells compared to wild-type CY184 cells as expected. But the sensitivity of PKC inhibitors towards topoisomerase I-deficient CY154 cells also remains low compared to wildtype CY184 cells (Figure 6c). Furthermore, it was observed that immediately after $2 \mathrm{~h}$ of treatment with withaferin $\mathrm{A}$ or staurosporine, the mitochondrial membrane potential was lost in the wild-type cells (CY184) compared to the topoisomerase I-deficient CY154 cells. This result is consistent with that obtained after treatment with CPT (Table 1). Together, these findings suggest that topoisomerase I cleavage complexes contribute to apoptosis.

\section{Discussion}

The molecular mechanism associated with PCD activation has been widely explored in mammalian cells, but not yet precisely understood in kinetoplastid parasites. Mounting evidences have indicated that changes in the phosphorylation state of proteins are important during $P C D$ induced by different agents in higher eucaryotes. ${ }^{28}$ Altogether, these observations and our present studies indicate that alterations of the phosphorylation state of cytosolic proteins like PKC can efficiently trigger PCD in a wide range of cell systems from higher eucaryotes to lower unicellular eucaryotes.

In this study, we established that a steroidal lactone withaferin A inhibits PKC both in vitro and in vivo. Here we have used leishmanial cell lysate as a source for PKC to phosphorylate the peptide substrate in the presence or absence of withaferin $A$. We provide evidences in support of the fact that withaferin $A$ has a direct inhibitory effect on the

\footnotetext{
Figure 5 Treatment with withaferin A induces topoisomerase I-DNA complexes in cells but cannot interact with topoisomerase I directly. (a) Leishmanial cells were treated with $0.2 \%$ DMSO alone (lane 1 ), $15 \mu \mathrm{M}$ of withaferin A for $3 \mathrm{~h}$ (lane 2 ), $4 \mathrm{~h}$ (lane 3), $5 \mathrm{~h}$ (lane 4 ), $15 \mu \mathrm{M}$ of staurosporine for $4 \mathrm{~h}$ (lane 5 ), $50 \mu \mathrm{M}$ of CPT for $3 \mathrm{~h}$ (lane 6) and with NAC before treatment with withaferin A (lane 7). Stabilization of topoisomerase I-mediated cleavable complex was determined by immunoband depletion assay. (b) Relaxation of supercoiled pBS (SK +) DNA (lane 1) with reconstituted LdTOPILS (lane 2) in the presence of $20 \mu \mathrm{M}$ (lane 3), $40 \mu \mathrm{M}$ (lane 4), $60 \mu \mathrm{M}$ (lane 5) and $80 \mu \mathrm{M}$ (lane 6) of withaferin A and $40 \mu \mathrm{M}$ (lane 7) and $80 \mu \mathrm{M}$ (lane 8) of staurosporine as well as with $50 \mu \mathrm{M}$ of CPT (lane 9) separately. The relaxation assay was also carried out with $\mathrm{CPT}$ in the presence of withaferin $\mathrm{A}$ (lane 10). (c) LdTOPILS-mediated cleavage reaction was performed as described in Materials and Methods. Lane 1: $1 \mu \mathrm{g}$ of supercoiled PHOT1 DNA; lane 2: with $40 \mathrm{U}$ of LdTOPILS after SDS-proteinase $\mathrm{K}$ treatment; lanes 3-6: same as lane 2 but with $20,40,60$ and $80 \mu \mathrm{M}$ of withaferin $\mathrm{A}$; lanes 7,8 , same as lane 2 but with 40 and $80 \mu \mathrm{M}$ of staurosporine; lane 9: same as lane 2 but with $60 \mu \mathrm{M}$ of CPT; lane 10: same as lane 2 but with both withaferin A and CPT. (d) Topoisomerase I activity was determined by relaxation of supercoiled pHOT1 DNA $(400 \mathrm{ng})$ in the presence of nuclear extracts equivalent to $10^{7}$ cells of differently treated cells. Lane 1:control DNA; lane 2: control nuclear extract; lane 3: nuclear extract from withaferin Atreated cells; lane 4: same as lane 3 but in the presence of $50 \mu \mathrm{M} \mathrm{CPT;} \mathrm{lane} \mathrm{5:}$ control nuclear lysate in the presence of $50 \mu \mathrm{M} \mathrm{CPT}$; lane 6 : nuclear lysate from CPT-treated cells
} 

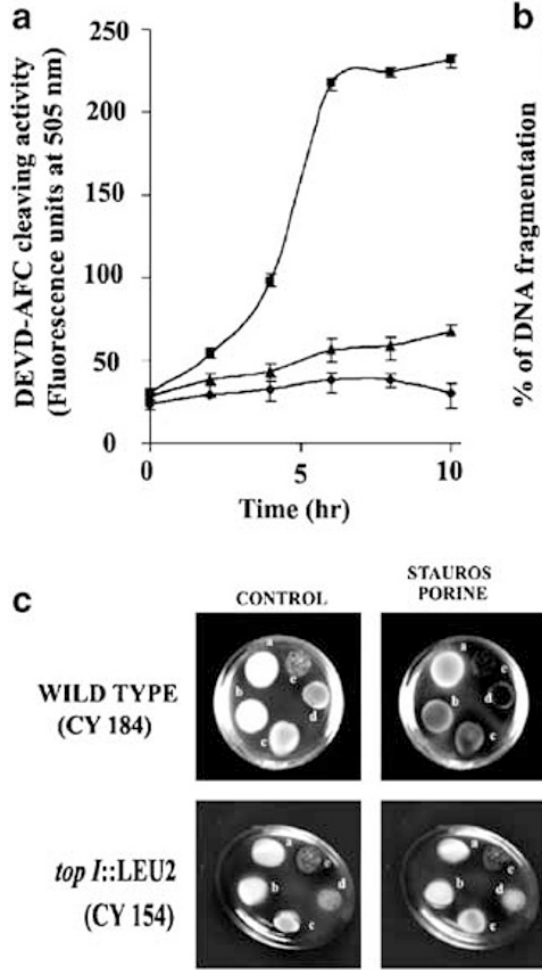

b
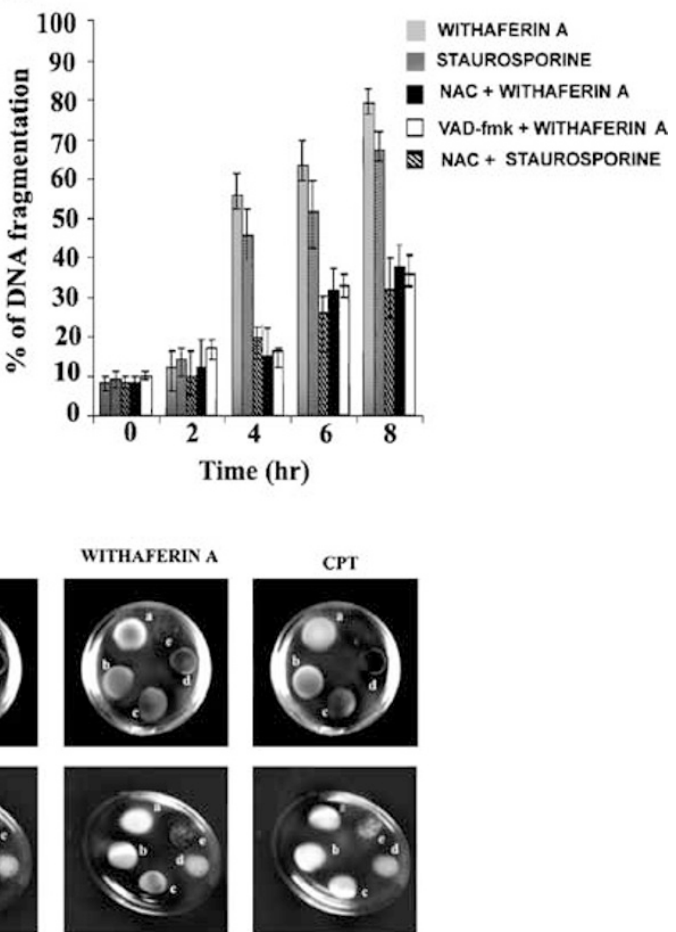

Figure 6 Determination of caspase-like protease activity and measurement of DNA fragmentation after treatment with withaferin A. (a) Cells were treated with $0.2 \%$ DMSO $(\bullet), 15 \mu \mathrm{M}$ of withaferin A $(\boldsymbol{\square})$ and with VAD-fmk before treatment with withaferin $\mathrm{A}(\boldsymbol{\Delta})$ and then DEVD-AFC cleavage activity was measured in these cells. (b) Percentage of DNA fragmentation was analyzed by TUNEL assay in differently treated cells. (c) Equal number of wild-type (CY184) and topoisomerase I-deficient yeast cells (CY 154) were serially diluted to 10 -fold (a-e) and then spotted on plates containing $50 \mu \mathrm{g} / \mathrm{ml} \mathrm{CPT,} 50 \mu \mathrm{g} / \mathrm{ml}$ staurosporine and $50 \mu \mathrm{g} / \mathrm{ml}$ withaferin A as described in Materials and Methods

Table 1 Effects of treatments with CPT, staurosporine and withaferin A on the mitochondrial membrane potential of yeast cells as measured by fluorescence of $\mathrm{JC} 1$ dye

\begin{tabular}{lc}
\hline Name of events & Ratio of $\mathbf{5 9 0 / 5 3 0}$ \\
\hline CY184 & $6.5 \pm 1.23$ \\
CY184+CPT & $2.82 \pm 0.73$ \\
CY184+STAUROSPORINE & $3.16 \pm 0.94$ \\
CY184+WITHAFERIN A & $3.02 \pm 0.19$ \\
CY154 & $6.85 \pm 1.56$ \\
CY154+CPT & $5.14 \pm 1.92$ \\
CY154+STAUROSPORINE & $4.67 \pm 0.83$ \\
CY154+WITHAFERIN A & $4.72 \pm 0.42$ \\
\hline
\end{tabular}

phosphorylation of the peptide substrate where rat brain PKC was used as the enzyme.

Cellular exposure to staurosporine or withaferin A induces mitochondrial outer membrane permeabilization. Downstream activation of proteases (caspases) causes DNA fragmentation. This was evident from the observation that treatment with VAD-fmk before treatment with withaferin $A$ decreases the number of TUNEL-positive cells but only to the extent of $47 \%$. This has led to the notion that there must be other mechanisms involved in DNA fragmentation (Figure 7). We found that topoisomerase I-mediated stabilization of cleavable complexes also contributes to DNA fragmentation. To interpret these observations, the following questions need to be addressed. First, how topoisomerase I-DNA cleavable complex is stabilized inside leishmanial cells during treatment with PKC inhibitors, and second, what is the probable mechanism by which topoisomerase I-DNA complex participates in DNA fragmentation.

Topoisomerase I-DNA cleavage complexes can be trapped by specific inhibitors such as CPT, which binds at the topoisomerase I-DNA interface and traps the cleavable complexes by preventing the DNA religation step. ${ }^{29}$ Moreover, DNA modifications such as oxidative base lesions, mismatches, abasic sites and DNA single-strand breaks can also trap topoisomerase cleavage complexes by interfering with the nicking-closing activities of the enzyme. ${ }^{25,30}$ Withaferin A or staurosporine does not interact directly with the enzyme. Here we have observed that treatment with withaferin A causes an increase in ROS production after inhibition of PKC inside cells. This in turn causes an increase in oxidative DNA lesions that can trap topoisomerase Imediated cleavable complex formation during apoptosis. This is evident from the observation that treatment with NAC, before treatment with withaferin $A$, causes a decrease in oxidative stress as well as the reappearance of immunoband of topoisomerase I. Therefore, our result further confirms the fact that oxidative DNA lesion is a common mechanism for trapping of topoisomerase I cleavable complexes during apoptosis after treatment with PKC inhibitors.

But the major question regarding the role of topoisomerase I-DNA cleavable complex in apoptosis remains to be 


\section{Withaferin A treatment \\ PKC INHIBITION \\ $\downarrow$}

loss of mitochondrial membrane potential

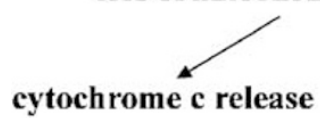

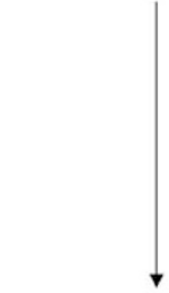

caspase activation

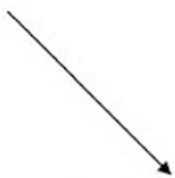

DNA fragmentation

\section{Cell Death}

Figure 7 Proposed model for withaferin A-induced apoptosis-like death in leishmanial cells

answered. Topoisomerase I, although a ubiquitous enzyme in cells, possibly participates in apoptosis by directly generating DNA breaks like an 'apoptotic nuclease'. Moreover, we have found that wild-type yeast cells (CY184) lose the mitochondrial membrane potential very rapidly compared to the topoisomerase I-deficient yeast cells (CY154) after treatment with protein kinase inhibitors. This result suggests that expression of topoisomerase I confers sensitivity to PKC inhibitors and the absence of topoisomerase I only reduces but does not abrogate the apoptotic process. Therefore, topoisomerase I could act in concert with other apoptotic nucleases like caspase-activated DNase in leishmanial cells to propagate the process.

In conclusion, our study demonstrates for the first time that a novel PKC inhibitor, withaferin A, induces PCD in kinetoplastid parasites in a manner substantially different from higher eucaryotic cells. Inhibition of PKC by withaferin A likely represents an essential event responsible for the propagation of apoptosis and can act as a central regulator of the apoptotic machineries. Moreover, it was also established that both casapase-activated DNase and ROS-mediated formation of topoisomerase I-DNA suicidal complex are responsible for DNA fragmentation. So understanding the molecular mechanism of apoptotic cell death pathway provides the opportunities for discovering and evaluating molecular targets for drug designing, which now forms a rational basis for development of improved therapy against leishmaniasis.

\section{Materials and Methods}

Isolation of withaferin A. The crushed air-dried leaves of Withania somnifera Dun. $(1.5 \mathrm{~kg})$, defatted with petroleum-ether $\left(60-80^{\circ} \mathrm{C}\right)$, were soxhleted with methanol for $48 \mathrm{~h}$. The methanol extract was successively fractionated with chloroform and $n$-butanol. On removal of the solvent under reduced pressure, the $n$-butanol extract $(220 \mathrm{~g})$ was chomatographed over silica gel (60-120 mesh) and the column was eluted with $12 \%$ methanolic chloroform to yield a compound $(1.2 \mathrm{~g})$, crystallized from acetone-petroleum-ether as prisms, m.p. $252-253^{\circ} \mathrm{C}, \mathrm{M}^{+} 470,[\alpha]_{\mathrm{D}}^{28}+125^{\circ}\left(\mathrm{CHCl}_{3}, \mathrm{C} 1.30\right)$. The homogeneity of the compound was determined by TLC and HPLC (reverse phase) and the structure of the compound was established by detailed spectral studies (IR, ${ }^{1} \mathrm{H}$ NMR, 2D NMR and MS). Finally, the compound was identified as withaferin $A^{16}$ by direct comparison with an authentic sample.

Parasite culture and maintenance. $L$. donovani strain AG 83 promastigotes were grown at $22^{\circ} \mathrm{C}$ in M199 liquid media supplemented with $10 \%$ fetal calf serum.

Preparation of cell lysates and PKC assay. Cell lysates of treated and untreated cells were prepared as described. ${ }^{22}$ Briefly, the cells were washed with cold $150 \mathrm{mM} \mathrm{NaCl}$ and extracted with a buffer containing $1 \%(\mathrm{v} / \mathrm{v})$ glycerol, $2 \mathrm{mM}$ EDTA, $2 \mathrm{mM}$ EGTA, $2 \mathrm{mM}$ PMSF, $0.5 \mathrm{mg} / \mathrm{ml}$ leupeptin, $2 \mathrm{mM} \beta$ mercaptoethanol and $25 \mathrm{mM}$ Tris- $\mathrm{HCl}, \mathrm{pH}$ 7.5. The material was homogenized with a glass/glass homogenizer and centrifuged at $15000 \times g$ for $10 \mathrm{~min}$ at $4^{\circ} \mathrm{C}$. The supernatant was collected and investigated for kinase activity with HCV (1487-1500) as substrate. The activities of protein kinases towards peptide substrate were analyzed by SDSPAGE as described. ${ }^{22}$ The reaction mixture $(50 \mu \mathrm{l})$ was incubated at $30^{\circ} \mathrm{C}$ for $30 \mathrm{~min}$ in a buffer containing $20 \mathrm{mM}$ Tris- $\mathrm{HCl}, \mathrm{pH} 7.5,10 \%$ (v/v) glycerol, $0.05 \%$ (v/v) Triton X-100, $1 \mathrm{mM}$ 2-mercaptoethanol, $6 \mathrm{mM} \mathrm{CaCl}_{2}, 0.1 \mathrm{mg} / \mathrm{ml} \mathrm{BSA}, 50 \mu \mathrm{M}$ [ $\left.\gamma^{32} \mathrm{P}\right] A T P(0.5 \mu \mathrm{Ci}), 20 \mu \mathrm{g} / \mathrm{ml} \mathrm{PS}, 2 \mu \mathrm{g} / \mathrm{ml} \mathrm{DG}, 0.2 \mathrm{mM}$ PMSF and $1 \mu \mathrm{g}$ of peptide substrate (Arg ${ }^{1487}$-Arg-Gly-Arg-Th-Gly-Arg-Gly-Arg-Arg-Gly-lle-Phe-Arg ${ }^{1500}$ ) with cell extract equivalent to $5 \times 10^{7}$ cells. For assay with rat brain kinase (purchased from Calbiochem), addition of cell extract is omitted. The reaction was terminated by addition of $20 \mu \mathrm{l} \mathrm{sample} \mathrm{buffer} \mathrm{and} \mathrm{boiling} \mathrm{for} 3 \mathrm{~min}$. The samples were applied to $20 \%$ SDS-PAGE. After staining with Coomassie brilliant blue, gels were dried and exposed to $\mathrm{X}$-ray film at $-70^{\circ} \mathrm{C}$. Subsequently, peptides were cutout and ${ }^{32} \mathrm{P}$ incorporation was measured as Cerenkov radiation.

Detection of cytochrome $c$ release. Treated and untreated cells were harvested and washed twice with $1 \times$ PBS, suspended in cell fractionation buffer (Apo Alert ${ }^{\mathrm{TM}}$ cell fractionation kit) and homogenized. After the separation of cytosolic and mitochondrial fraction, $50 \mu \mathrm{g}$ each of cytosolic proteins was separated on $12 \%$ SDS-PAGE and immunoblotted with the rabbit polyclonal cytochrome $c$ antibody. Alkaline phosphatase-conjugated secondary antibody was used and protein bands were visualized by NBT and BCIP color reaction. ${ }^{23}$

DNA fragmentation assay. To know the alterations in DNA content in the nucleus, treated and untreated $L$. donovani promastigote cells were fixed with $2 \%$ paraformaldehyde and incubated with $0.2 \%$ Triton $X-100$ for $5 \mathrm{~min}$ for permeabilization and layered with terminal deoxynucleotidyl transferase reaction mixture containing FITC-labeled dUTP for $1 \mathrm{~h}$ at $37^{\circ} \mathrm{C}$ according to the manufacturer's protocol (Apo Alert ${ }^{\mathrm{TM}}$ DNA fragmentation assay kit). Cells were stained with propidium iodide and visualized with TCS-SP Leica confocal microscope using dual pass FITC/PI filter set. The number of TUNEL-positive cells was counted in each case. ${ }^{23}$

Double staining with Annexin $\mathrm{V}$ and propidium iodide. Externalization of phosphatidylserine on the outer membrane of untreated and withaferin A-treated promastigotes was measured by the binding of annexin V-FITC and PI using an annexin V-FLUOS staining kit (Roche Diagnostics). Cells were visualized with TCS-SP Leica confocal microscope using dual FITC/PI filter set. Total cells versus annexin V-labeled cells was calculated and data expressed as percentage of apoptotic cells. It should be noted that 100 cells per group with identical morphology were calculated for each condition. ${ }^{23}$

Purification of recombinant proteins and reconstitution of topoisomerase I activity. Escherichia coli BL21 (DE3) pLysS cells harboring $p E T 16 b L d T O P 1 L$ and $p E T 16 b L d T O P 1 S$ were separately induced at $\mathrm{OD}_{600}=0.6$ with $0.5 \mathrm{mM} \mathrm{IPTG}$ at $22^{\circ} \mathrm{C}$ for $12 \mathrm{~h}$. Cells harvested from $1 \mathrm{I}$ of culture 
were separately lysed by lysozyme/sonication and the proteins were purified through $\mathrm{Ni}^{2+}$-NTA agarose column (Qiagen) followed by phosphocellulose column ( $\mathrm{P} 11$ cellulose, Whatman) as described previously. ${ }^{26}$ Finally, the purified proteins LdTOP1L and LdTOP1S were stored at $-70^{\circ} \mathrm{C}$. The concentrations of purified proteins were quantified by Bradford reaction using a Bio-Rad Protein Estimation Kit according to the manufacturer's protocol.

Purified LdTOP1L were mixed with purified LdTOP1S separately at a molar ratio of $1: 1$ at a total protein concentration of $0.5 \mathrm{mg} / \mathrm{ml}$ in reconstitution buffer $(50 \mathrm{mM}$ potassium phosphate, pH 7.5, $0.5 \mathrm{mM}$ DTT, $1 \mathrm{mM}$ EDTA, $0.1 \mathrm{mM}$ PMSF, $10 \%$ glycerol). The mix was dialyzed overnight at $4{ }^{\circ} \mathrm{C}$ and the dialyzed fractions were used for the plasmid relaxation activity. ${ }^{26}$

Immunoband depletion assay. Leishmanial cells $\left(1 \times 10^{7}\right)$ were cultured for 3 days at $22^{\circ} \mathrm{C}$ with or without drugs. Nuclear fraction was isolated as described. ${ }^{31}$ Briefly, cells were suspended in hypotonic buffer $(10 \mathrm{mM}$ Tris- $\mathrm{HCl}, \mathrm{pH}$ 7.5, $1 \mathrm{mM}$ EDTA, $0.1 \mathrm{mM}$ EGTA, $1 \mathrm{mM}$ PMSF, $1 \mathrm{mM}$ benzamidine hydrochloride and $5 \mathrm{mM}$ DTT) and homogenized. The homogenate was centrifuged for $10 \mathrm{~min}$ at $10000 \times g$. The pellets were washed and were the source of nuclear fraction. Then nuclear fraction was lysed by $1 \%$ SDS. Samples were subjected to SDS-PAGE $(10 \%)$, and proteins that had entered the gel were electrophoretically transferred to nitrocellulose membranes. Immunoblotting of immobilized proteins was carried out using a mouse antibody raised against LdTOP1S. ${ }^{26}$

Plasmid relaxation assay. The type I DNA topoisomerase was assayed by decreased mobility of the relaxed isomers of supercoiled pBluescript $\left(\mathrm{SK}^{+}\right)$DNA in an agarose gel. Relaxation assay was carried out as described ${ }^{26}$ with LdTOP1LS in the relaxation buffer $(25 \mathrm{mM}$ Tris- $\mathrm{HCl}, \mathrm{pH} 7.5,5 \%$ glycerol, $0.5 \mathrm{mM}$ DTT, $10 \mathrm{mM}$ $\mathrm{MgCl}_{2}, 50 \mathrm{mM} \mathrm{KCl}, 2.5 \mathrm{mM}$ EDTA and $150 \mu \mathrm{g} / \mathrm{ml} \mathrm{BSA}$ ), and supercoiled pBluescript $\left(\mathrm{SK}^{+}\right)$DNA (85-95\% were negatively supercoiled with the remaining being nicked circles). The relaxation assay was performed in the presence of CPT, staurosporine and withaferin A separately. The amount of supercoiled monomer DNA band fluorescence after $\mathrm{EtBr}$ staining was quantitated. Relaxation assay was also performed with nuclear extracts from differently treated leishmanial cells.

DNA cleavage assay. Reaction mixtures $(50 \mu \mathrm{l})$ containing $50 \mathrm{mM}$ Tris- $\mathrm{HCl}$, $\mathrm{pH} 7.5,2 \mathrm{mM} \mathrm{MgCl} 2,50 \mathrm{mM} \mathrm{KCl}, 0.2 \mathrm{mM}$ DTT, $0.5 \mathrm{mM}$ EDTA, $30 \mu \mathrm{g} / \mathrm{ml} \mathrm{BSA}$, $20 \mu \mathrm{g} / \mathrm{ml}$ pHOT1 DNA, $40 \mathrm{U}$ of $L$. donovani topoisomerase I and drugs were incubated at $37^{\circ} \mathrm{C}$ for $30 \mathrm{~min}$. The reactions were terminated by adding $1 \%$ SDS and $150 \mu \mathrm{g} / \mathrm{ml}$ proteinase $\mathrm{K}$, and incubated further for $1 \mathrm{~h}$ at $37^{\circ} \mathrm{C}$. DNA samples were electrophoresed in $1 \%$ agarose gel containing $0.5 \mu \mathrm{g} / \mathrm{ml}$ ethidium bromide to resolve the more slowly migrating nicked products (form II) from the supercoiled molecules (form I). ${ }^{26}$

Detection of oxidative DNA damage. After drug treatment, cells were permeabilized in hypotonic buffer $(10 \mathrm{mM}$ Tris- $\mathrm{HCl}, \mathrm{pH} 7.8,70 \mathrm{mM} \mathrm{NaCl}, 1 \mathrm{mM}$ EDTA, $1 \mathrm{mM}$ DTT) containing $0.05 \%$ Triton $\mathrm{X}-100$ at $4{ }^{\circ} \mathrm{C}$ for $15 \mathrm{~min}$ by gentle mixing. Fpg $(1 \mathrm{mg} / \mathrm{ml})$ was added and further incubated for $30 \mathrm{~min}$ at $25^{\circ} \mathrm{C}$. DNA breaks were analyzed by alkaline comet assay ${ }^{32}$ with some modifications. Briefly 5000-10 000 cells were mixed with $100 \mu \mathrm{l}$ of $0.75 \%$ low-melting agarose and kept at $37^{\circ} \mathrm{C}$. The agarose cell suspension was spread on polylysine-coated coverslips. The preparations were left on a chilled plate for 5 min before lysis $(0.03 \mathrm{M} \mathrm{NaOH}$, $1 \mathrm{M} \mathrm{NaCl}, 2 \mathrm{mM}$ EDTA, $0.5 \% \mathrm{~N}$-lauryl sarcosyl) for $1.5 \mathrm{~h}$ and thereafter equilibrated $(0.03 \mathrm{M} \mathrm{NaOH}, 2 \mathrm{mM}$ EDTA) for $1 \mathrm{~h}$. Electrophoresis of the agarose-imbedded cells was run at $0.67 \mathrm{~V} / \mathrm{cm}$ for $20 \mathrm{~min}$ in the same solution. The agarose gel was neutralized in $0.4 \mathrm{M}$ Tris- $\mathrm{HCl}, \mathrm{pH}$ 7.5. Cells were then stained with EtBr. Analysis of the DNA that migrated from the nuclei, the tail moment, was carried out using an Olympus fluorescence microscope aided by the Kinetic Imaging Komet II system.

Drug sensitivity assays. Equal number of wild-type (CY184) and mutant top1::LEU2 (CY154) yeast cells (kindly provided by Michael F Chistman) were serially diluted to 10 -fold and $5 \mu$ laliquots were spotted on YPD plates containing $50 \mu \mathrm{g} / \mathrm{ml} \mathrm{CPT}, 50 \mu \mathrm{g} / \mathrm{ml}$ staurosporine, $50 \mu \mathrm{g} / \mathrm{ml}$ withaferin A separately and buffered with $25 \mathrm{mM} \mathrm{HEPES}, \mathrm{pH}$ 7.2. Control plates contained final concentrations of $0.25 \%$ DMSO and $25 \mathrm{mM}$ HEPES, $\mathrm{pH} 7.2$. Plates were incubated at $30^{\circ} \mathrm{C}$ for 2 days. $^{33}$ The genetic descriptions of the yeast strains are as follows

Measurement of mitochondrial membrane potential. Mitochondrial transmembrane potential was investigated using JC1 dye. Briefly, leishmanial cells after different treatments were harvested and washed with $1 \times$ PBS. Cells were
Yeast strain CY184

CY154

CY143

Description

MAT $\alpha$ ade 2-1 ura 3-1 his 3-11, 15 trp 1-1 leu 2-3,

112 can $1-100$ rDNA :: ADE 2

MATa top1-7 ::LEU2 in CY143

MAT $\alpha$ ade 2-1 ura 3-1 his 3-11, 15 trp 1-1 leu 2-3,

112 can $1-100$ rDNA :: URA 3

then incubated at $37^{\circ} \mathrm{C}$ in $5 \% \mathrm{CO}_{2}$ incubator for $1 \mathrm{~h}$ with a final concentration of $\mathrm{JC} 1$ dye at $5 \mu \mathrm{g} / \mu \mathrm{l}$ (according to the manufacturer's protocol). Cells were then analyzed by flow cytometry, where FL-1 channel indicates the mean green fluorescence intensity. Flow cytometry data presented here are representative of two experiments. $^{23}$

Mitochondrial membrane potential of yeast cells was measured as described. ${ }^{34}$ Two milliliter of treated and untreated cell suspensions (OD 20.0) was pelleted down and washed with spheroplast buffer $(1 \mathrm{M}$ sorbitol, $50 \mathrm{mM}$ Tris- $\mathrm{HCl}, \mathrm{pH} 7.5,2 \mathrm{mM}$ $\mathrm{MgCl}_{2}, 10 \mathrm{mM}$ DTT and $10 \mathrm{mM}$ sodium azide). Cells were then pelleted, lyticase was added and kept in the dark at room temperature for $30 \mathrm{~min}$. Cells were washed with water and incubated at $37^{\circ} \mathrm{C}$ in $5 \% \mathrm{CO}_{2}$ incubator for $1 \mathrm{~h}$ with a final concentration of $\mathrm{JC} 1$ at $5 \mu \mathrm{g} / \mu \mathrm{l}$ (according to the manufacturer's protocol). Cells were then analyzed by spectrophotometer.

Measurement of ROS level and GSH level. Intracellular ROS level was measured in treated and untreated cells as described. ${ }^{23}$ Briefly, cells $\left(2 \times 10^{7}\right)$ after different treatments were washed and resuspended in $500 \mu \mathrm{l}$ of medium M199 and were loaded with a cell-permeant probe $\mathrm{H}_{2} \mathrm{DCFDA}$ for $1 \mathrm{~h}$. The green fluorescence of DCF was recorded at $515 \mathrm{~nm}$ by spectrofluorometer. GSH level was measured by monochlorobimane (MCB) dye. ${ }^{23}$ L. donovani promastigotes $\left(2.5 \times 10^{6}\right.$ cells) were treated with or without withaferin $A$ at different times. Cells were then pelleted down and lysed by cell lysis buffer according to the manufacturer's protocol (Apo Alert $^{\mathrm{TM}}$ glutathione assay kit). Cell lysates were incubated with MCB $(2 \mathrm{mM})$ for $2 \mathrm{~h}$ at $22{ }^{\circ} \mathrm{C}$. The decrease in glutathione levels in the extracts of nonapoptotic and apoptotic cells was detected by fluorometer with $395 \mathrm{~nm}$ excitation and $480 \mathrm{~nm}$ emission wavelength.

Determination of caspase-like protease activity. $L$. donovani promastigotes $\left(2.5 \times 10^{6}\right)$ were treated with or without withaferin $A$ for different time periods. Cells were then pelleted and lysed by cell lysis buffer according to the manufacturer's protocol (Apo Alert ${ }^{\mathrm{TM}}$ caspase assay kit). Cell lysates were incubated with respective caspase buffers to detect CED3/CPP32 group of protease activity. A fluorogenic peptide substrate, DEVD-AFC at $100 \mu \mathrm{M}$ and $1 \times$ reaction buffer containing $100 \mathrm{mM}$ DTT were added to corresponding cell lysates to measure the activity of CED3/CPP32 group of proteases. In a parallel set of reactions, $1 \mu \mathrm{l}$ o CED3/CPP32 group of protease inhibitor was added to the reaction before the addition of cell lysates. AFC release was measured after incubating these samples at $37^{\circ} \mathrm{C}$ for $2 \mathrm{~h}$ by fluorometer with $380 \mathrm{~nm}$ excitation and $460 \mathrm{~nm}$ emission. ${ }^{23}$

Statistical analysis. Data are expressed as mean \pm S.D. unless mentioned otherwise. Comparisons were made between different treatments using unpaired Student's t-test.

Acknowledgements. We thank Professor S Roy, the director of our institute, for his interest in this work. NS is supported by Senior Research Fellowship from the Council for Scientific and Industrial Research, Government of India. This work was supported by grants from Network Project SMM-003 of Council of Scientific and Industrial Research (CSIR), Government of India to HKM.

1. Evan G. Why we live and why we die. Chem Biol 1994; 1: 137-141.

2. Williams GT. Programmed cell death: a fundamental protective response to pathogens. Trends Microbiol 1994; 2: 463-464.

3. Welburn SC, Barcinski MA, Williams GT. Programmed cell death in trypanosomatids. Parasitol Today 1997; 13: 22-26.

4. Zangger $\mathrm{H}$, Mottram JC, Fasel N. Cell death in Leishmania induced by stress and differentiation: programmed cell death or necrosis? Cell Death Differ 2002; 9: 1126-1139.

5. Kikkawa U, Kishimoto A, Nishizuka $Y$. The protein kinase $C$ family: heterogeneity and its implications. Annu Rev Biochem 1989; 58: 31-44.

6. Newton AC. Regulation of protein kinase C. Curr Opin Cell Biol 1997; 9: 161-167.

7. Bertrand R, Solary E, O'Connor P, Kohn KW, Pommier Y. Induction of a common pathway of apoptosis by staurosporine. Exp Cell Res 1994; 211: 314-321. 
8. Gekeler V, Wilisch A, Probst G, Kugel A, Brischwein K, Engelcke M et al. Staurosporine suppresses replicon initiation in mammalian cells. FEBS Lett 1993; 327: 150-156.

9. Gescher A. Staurosporine analogues - pharmacological toys or useful antitumour agents? Crit Rev Oncol Hematol 2000; 34: 127-135.

10. Nishi K, Schnier JB, Bradbury EM. The accumulation of cyclin-dependent kinase inhibito p27kip1 is a primary response to staurosporine and independent of $\mathrm{G} 1$ cell cycle arrest. Exp Cell Res 1998; 243: 222-231.

11. Kawakami K, Futami H, Takahara J, Yamaguchi K. UCN-01, 7-hydroxyl-staurosporine inhibits kinase activity of cyclin-dependent kinases and reduces the phosphorylation of the retinoblastoma susceptibility gene product in A549 human lung cancer cell line. Biochem Biophys Res Commun 1996; 219: 778-783.

12. Akiyama T, Yoshida T, Tsujita T, Shimizu M, Mizukami $T$, Okabe $M$ et al. G1 phase accumulation induced by UCN-01 is associated with dephosphorylation of Rb and CDK2 proteins as well as induction of CDK inhibitor p21/Cip1/WAF1/Sdi1 in p53-mutated human epidermoid carcinoma A431. Cells Cancer Res 1997; 57: 1495-1501.

13. Shao RG, Shimizu T, Pommier Y. 7-Hydroxystaurosporine (UCN-01) induces apoptosis in human colon carcinoma and leukemia cells independently of p53. Exp Cell Res 1997; 234 388-397.

14. Han EK, Begemann M, Sgambato A, Soh JW, Doki Y, Xing WQ et al. Increased expression of cyclin D1 in a murine mammary epithelial cell line induces p27kip1, inhibits growth, and enhances apoptosis. Cell Growth Differ 1996; 7: 699-710.

15. Shohat B, Gitter S, Abraham A, Lavie D. Anti-tumor activity of withaferin A (NSC-101088). Cancer Chemother Rep 1967; 51: 271-276.

16. Kupchan SM, Anderson WK, Bollinger P, Doskotch RW, Smith RM, Renauld JA et al. Tumor inhibitors. XXXIX. Active principles of Acnistus arborescens. Isolation and structural and spectral studies of withaferin A and withacnistin. J Org Chem 1969; 34 3858-3866.

17. Furmanowa M, Gajdzis-Kuls D, Ruszkowska J, Czarnocki Z, Obidoska G, Sadowska A et al. In vitro propagation of Withania somnifera and isolation of withanolides with immunosuppressive activity. Planta Med 2001; 67: 146-149.

18. Fugner A. Inhibition of immunologically induced inflammation by the plant steroid withaferin A. Arzneimittelforschung 1973; 23: 932-935.

19. Shohat B, Kirson I, Lavie D. Immunosuppressive activity of two plant steroidal lactones withaferin A and withanolide E. Biomed 1978; 28: 18-24.

20. Falsey RR, Marron MT, Gunaherath GM, Shirahatti N, Mahadevan D, Gunatilaka AA et al. Actin microfilament aggregation induced by withaferin $\mathrm{A}$ is mediated by annexin II. Nat Chem Biol 2006; 2: 33-38.

21. Iwu MM, Jackson JE, Schuster BG. Medicinal plants in the fight against leishmaniasis. Parasitol Today 1994; 10: 65-68.
22. Borowski $\mathrm{P}$, Resch $\mathrm{K}$, Schmitz $\mathrm{H}$, Heiland $\mathrm{M}$. A synthetic peptide derived from the nonstructural protein 3 of hepatitis $\mathrm{C}$ virus serves as a specific substrate for PKC. Biol Chem 2000; 381: 19-27.

23. Sen N, Das BB, Ganguly A, Mukherjee T, Tripathi G, Bandyopadhyay S et al. Camptothecin induced mitochondrial dysfunction leading to programmed cell death in unicellular hemoflagellate Leishmania donovani. Cell Death Differ 2004; 11: 924-936.

24. Pourquier P, Pilon AA, Kohlhagen G, Mazumder A, Sharma A, Pommier Y. Trapping of mammalian topoisomerase I and recombinations induced by damaged DNA containing nicks or gaps. Importance of DNA end phosphorylation and camptothecin effects. J Biol Chem 1997; 272: 26441-26447.

25. Pourquier P, Ueng LM, Fertala J, Wang D, Park HJ, Essigmann JM et at. Induction of reversible complexes between eukaryotic DNA topoisomerase I and DNA-containing oxidative base damages. 7,8-dihydro-8-oxoguanine and 5-hydroxycytosine. J Biol Chem 1999; 274: 8516-8523.

26. Das BB, Sen N, Ganguly A, Majumder HK. Reconstitution and functional characterization of the unusual bi-subunit type I DNA topoisomerase from Leishmania donovani. FEBS Lett 2004; 565: 81-88.

27. Staker BL, Hjerrild K, Feese MD, Behnke CA, Burgin Jr AB, Stewart L. The mechanism of topoisomerase I poisoning by a camptothecin analog. Proc Natl Acad Sci USA 2002; 99: 15387-15392.

28. Uckun FM, Tuel-Ahlgren L, Song CW, Waddick K, Myers DE, Kirihara J et al. lonizing radiation stimulates unidentified tyrosine-specific protein kinases in human B-lymphocyte precursors, triggering apoptosis and clonogenic cell death. Proc Natl Acad Sci USA 1992; 89: 9005-9009.

29. Meng LH, Liao ZY, Pommier Y. Non-camptothecin DNA topoisomerase I inhibitors in cancer therapy. Curr Top Med Chem 2003; 3: 305-320.

30. Pourquier P, Bjornsti MA, Pommier Y. Induction of topoisomerase I cleavage complexes by the vinyl chloride adduct 1, N6-ethenoadenine. J Biol Chem 1998; 273: 27245-27249.

31. Boege F, Straub T, Keh A, Boesenberg C, Chistiansen K, Andersen A et al. Selected novel flavones inhibit the DNA binding or the DNA religation step of eukaryotic topoisomerase I. J Biol Chem 1996; 271: 2262-2270.

32. Ismail IH, Nystrom S, Nygren J, Hammarsten O. Activation of ataxia telangiectasia mutated by DNA strand break-inducing agents correlates closely with the number of DNA double strand breaks. J Biol Chem 2005; 280: 4649-4655.

33. Walowsky C, Fitzhugh DJ, Castano IB, Ju JY, Levin NA, Christman MF. The topoisomerase-related function gene TRF4 affects cellular sensitivity to the anti-tumor agent camptothecin. J Biol Chem 1999; 274: 7302-7308.

34. Pina-Vaz C, Sansonetty F, Rodrigues AG, Costa-Oliveira S, Tavares C, Martinez-deOliveira J. Cytometric approach for a rapid evaluation of susceptibility of Candida strains to antifungals. Clin Microbiol Infect 2001; 7: 609-618. 